\title{
Bringing the Truth Home: the role of oral history and testimony in building and fragmenting Australian collective history and the Stolen Generations
}

\author{
Koreen Cueto \\ University of Technology Sydney, Faculty of Arts and Social Sciences, PO Box 123, Ultimo NSW \\ 2017, Australia.koreen.cueto@student.uts.edu.au
}

DOI: https://doi.org/10.5130/nesais.v4i1.1524

\begin{abstract}
Australia's fraught colonial past has made the search for a collective history exceptionally difficult; history wars surrounding policies of child removal in particular are a testament to the nation's fractured memory. This essay examines the role of oral history in the promotion of both truth and healing - not only for separated Indigenous families, but also for the collective national identity which has suffered as a result of colonial Australia's failure to pay heed to Indigenous voices.
\end{abstract}

Keywords: Stolen Generations; history wars; oral history

\section{Introduction}

The issue of Australian collective history and memory has been difficult since stories of the Stolen Generations began to emerge. The 'central truth' of child removal policies has since been littered with 'small truths', personal and localised accounts from those who experienced such policies (Read 2002). For the most part, the evidence gathered from the Bringing Them Home Inquiry, the largest study of the separation of Aboriginal and Torres Strait Islander children from their families, were oral testimonies. In this essay, I aim to explore the role of oral testimony in understanding the Stolen Generations narrative. First, I will explore the inception of the technique, bringing to light issues of validity. Next, I will demonstrate how the importance of oral testimonies lie not only in the factual accounts being given, but also in the underlying message seen through communication cues. The messages are vast and may include power relations and how the focus of the message may change depending on the time period and audience. Finally, I will briefly explore how engaging with oral testimony by both the individual giving it and the collective audience listening can be used as an instrument for healing. 


\section{Australian Collective History}

Academics such as Goodall (2008), Attwood (2001), Darian-Smith and Hamilton (2013) have observed that a collective history and memory play a large part in determining Australian identity. In the past, politicians such as John Howard have sought to "instrumentalise Australian history for political ends" (Bonnell and Crotty 2008, p. 151). In Future Directions, Howard called for a country that was proud of its heritage and shouldn't have to "apologise for pride in their culture, traditions, institutions and history"; "one Australia", not "an Australia of individual groups" (through McKenna 1997). Goodall further notes that in order for the past to have great importance and a great impact to constructions of identity, they should be 'consensual accounts' $(2008$, p. 12). Therefore, it is no surprise that for decades Australians have sought an account they can be proud of. For example, Australians have previously revelled in the spirit of the Anzacs with public commemorations, museum exhibitions and other activities and have deemed war memorials to be 'sacred spaces' (Darian-Smith and Hamilton 2013, p. 373). However, when faced with relations of Indigenous people, Australians seem a little more divided.

The History Wars, as they've come to be known, refer to the cultural and intellectual struggle over the nature of Indigenous treatment "and the place it should assume in Australian self-understanding" (Manne 2009). Stories of Indigenous dispossession and the removal of children from parents in what has come to be known as the Stolen Generations has become a narrative "central to Australian historical consciousness" (Attwood 2001, p. 183). Insights from the Bringing Them Home (BTH) Report of 1997 will be discussed later in this essay. Attwood argues the surfacing of such stories aren't a case of 'submerged history' rather a 'narrative accrual' (2001, p. 183). Nevertheless, stories brought forth through the mechanism of oral history and testimonies have challenged a collective Australian memory. The Stolen Generations narrative, Attwood describes, on one hand has "constituted for Indigenous Australians a condensation of their experience of dispossession" and on the other hand "provided settler Australians a focus for their sense of shame" (2001, p. 206). In response, there have been counterattacks, mainly by conservatives who are unwilling to accept "truths about Australian racism" (Attwood 2001, p. 206).

\section{Oral History and Small Truths}

According to recorded history by the North American Oral History Association, oral history was established in 1948 by historian Allan Nevins as a "modern technique for historical documentation" (through Thomson 1998, p. 581). The use of oral history as a documentation technique has been criticised since as 'positivist social sciences and traditional documentary historians' sought for a 'scientific' model on how to execute it. Furthermore, oral historians have recognised that the interview "is a relationship embedded within particular cultural practices and informed by culturally specific systems and relations of communication" (Thomson 1998, p. 582). In essence, oral historians need to be mindful of the contexts they're dealing with and should be vigilant in observing communication cues such as pauses, silences and jargon. In his overview of oral history, Thomson questions whether interview techniques to obtain oral history experiences are incompatible with Indigenous systems and relations of communication. Slim and Thompson conclude that it is "critically important to be aware of different conceptual and cultural dimensions" (through Thomson 1998, p. 583). 
There are many arguments against the validity and accuracy of oral histories, the most popular being the deterioration of memory over time and personal bias of both the interviewer and interviewee (Thomson 2013). Thomson quotes an Australian historian who wrote in 1979 that the world of "selective memory, later overlays and utter subjectivity... and where will it lead us? Not into history, but into myth" (1998, p. 585). However, other historians such as Michael Frisch argue that the strength of oral history lies precisely in its subjectivity. Oral history, he says, is "history as it really was", and gives insight to "how people make sense of their past, how they connect individual experience and its social context, how the past becomes part of the present, and how people use it to interpret their lives and the world around them" (through Thomson 1998, p. 586).

Oral histories are largely personal. For years, documenting history was 'essentially political', focusing on 'legislative and administrative developments' rather than on the lives of ordinary people during events (Thompson and Bornat 2000, p. 4). In contrast, oral history personalises the experience. I suggest that oral history contributes largely to the concept Read identifies as 'small truths'. Small truths, according to Read, are 'local variations' of historical events that may appear to undermine 'central truths'. However, small truths enhance central truths (Read 2002, p. 54-55). Read predominantly defines small truths to be details that may counter big truths, however for the purposes of this essay, I frame the definition of small truths to another detail he mentions: that being, the 'local and regional variations', a nod to Attwood's idea of narrative accrual, which the BTH report provides (2002, p. 54).

Read puts forward the notion that by the end of the 1970s, "several analogous 'big truths' about Aboriginal history began to emerge, or re-emerge" in Australia. That is, that Aboriginal Australians were "subjected to violent dispossession of their lands" (2002, p. 54). In following years, little truths began to arise. It is important for the little truths to circulate such narratives because it would be "irresponsible to let aspiring historians write as if history, even very heavily weighted moral history, is simple" (Read 2002, p. 59). Furthermore, the co-existence of small and larger truths leads to more "moral and balanced presentations." It is a historian's responsibility to "advance historical knowledge and understanding," especially in areas where not much currently exists (Read 2002, p. 59-60).

\section{The Stolen Generations and Oral History}

Following years of political agitation, then Attorney-General Michael Lavarch issued instructions to the Human Rights and Equal Opportunity Commission (HREOC) to "trace the laws, practices and policies under which Aboriginal children were removed from their families by duress or by force and to trace their effects" (Devitt 2009, p. 50). The BTH inquiry took place between December 1995 and April 1997 with a budget of $\$ 1.5$ million and received 777 oral and written submissions - some 535 from Indigenous witnesses who experienced separation and a combination of Indigenous organisations, government and church representatives, former mission staff, foster and adoptive parents and others making up the remaining 242 submissions (Devitt 2009). Since then, further oral testimonies regarding the Stolen Generations have also been circulated.

According to Devitt, the HREOC went to "great lengths to ensure Indigenous people would feel comfortable coming to the inquiry to tell their story" (2009, p. 56). Members of the Indigenous 
Advisory Council such as Nigel D'Souza pointed out that "people want to talk on an individual basis and that regardless of the collective situation, not all have the same experiences" (through Devitt 2009, p. 58). Furthermore, then Aboriginal and Torres Strait Islander Social Justice Commissioner Mick Dodson argued that "the success of the Inquiry will depend in part on the Inquiry's capacity to hear those stories" (through Devitt 2009, p. 58). The extensive use of oral testimony and autobiography in the Inquiry and the retelling of Stolen Generations' narratives have always been subject to scrutiny. Attwood mentions that the HREOC undertook "little if any original historical research" and that for most people and historians, the presentation of the Stolen Generations narrative lacked "important grounding in historical sources" that could verify what was being given in testimonies (2001, p. 209). However, Attwood interestingly points out later in his specific study of the Stolen Generations that the "importance of oral testimony may often lie not in its adherence to facts," but rather working with errors brought about by "imagination, symbolism, and desire" can reveal "more than factually correct accounts" (2001, p. 211). More often than not, histories being told at a certain period can expose power relations. This can be seen through testimonies that demonstrate a lack of knowledge by Indigenous Australians regarding government policies of assimilation during that time. Examples from the BTH Report can be seen below:

I was all upset and I didn't know what to do and I didn't know where we were going. I just thought: well, they're police, they must know what they're doing. I suppose I've got to go with them, they're taking me to see Mum. (Bringing Them Home Report, p. 3)

We travelled all day long. We didn't know what place we were going to, all I knew was we were going further and further away from home. (Bringing Them Home Report, p. 47)

In reflecting on the narrative of the Stolen Generations, Peter Read identifies a lack of 'historical knowledge' (through Attwood 2001, p. 185). Numerous accounts show that Indigenous people didn't know why they or their children were being removed and weren't aware that a larger amount of children were being removed from their families. Read suggests that had Indigenous people knew of this policy, "this history would have been" told earlier (through Attwood 2001, p. 185). This reveals a grand sense of powerlessness by Indigenous Australians at the hands of Protection Boards and others executing the policies.

Oral history and the emergence of small truths demonstrate that historical knowledge and narratives change over time. Attwood reminds us that there is always a difference between past events and the way it is recalled later; that "history is not what happened in the past but always the past represented and re-presented" (2001, p. 188). This is mainly because history-work is shaped by wider cultural and political discourses of the time. Within this idea, I refer back to Peter Read's work on small and central truths and recall his experience bringing both into public consciousness. As mentioned previously, Read claims big truths regarding Indigenous dispossession surfaced during the end of the 1970s. By the 1980s, he explains, this "central truth of separation based on oral history" were propagated and repeated throughout the media and finally "secure and accepted as part of the national story" through the Bringing Them Home Inquiry (2002, p. 56). However, arguments denying this narrative soon began to emerge with the ensuing History Wars. According to Read, critics denied multiple facets of the Stolen Generations narrative, their claims ranging from the number of separated 
Indigenous children being highly 'exaggerated' to the idea children were not stolen at all (2002, p. 57).

Furthermore, Goodall's research shows that conflict around the Stolen Generations provide insight into processes that occur when memories that are circulated are "mobilised to serve in public conflicts" (2002, p. 14). What appears to change is the focus and emphasis of the story. Speaking from her personal experience of interviewing Indigenous Australians and community discussions about the theme of removal in the 1970s, Goodall observes the wide array of experiences expressed and the differing feelings that came with them. Stories were tragic, painful, some ironic and others humorous. She points out that while the general events each individual described were consistent, their personal and unique memories, subject to re-examination and reflection from different angles, have developed 'new' significance over time (2002, p. 14). However, when faced in settings that required contributing on a broader scale, Goodall found that speakers set aside minor details to focus on the "starkly tragic and unequivocally unjust dimensions of those stories" (2002, p. 15).

\section{Oral History as Tool for Healing}

On a brief note, Devitt's (2009) research found that the study of trauma in light of the Stolen Generations is enhanced through oral testimonies due to the idea that speaking about trauma has a healing effect on individuals. Sangster (through Devitt 2009, p. 60) argues that testimony "links personal trauma with its political oppression" which in turn allows "individual and societal healing." In a similar way, oral testimonies as received by the HREOC were essential to healing the nation of its unjust past. The HREOC endeavoured to involve and engage the wider public to the injustices experienced by Indigenous people, and while for most part there was positive feedback and calls for reconciliation, others fell into prejudices that Indigenous people received 'preferential treatment' (Devitt 2009, p. 66). Thus, the reception of the inquiry is described to be 'inconsistent', indicating an 'unstable pattern of opinion'. The Coalition Government chose not to apologise publicly and decided against accepting responsibility to removal policies and practices (Devitt 2009, p. 67).

\section{Conclusion}

It is important for a nation to have a collective history and memory in order to have a nation-wide identity. That search for a collective history has been particularly difficult in Australia due to its colonial past, one major issue being the Stolen Generations and child removal policies. Oral testimonies have played a major role in how this narrative has been projected in the Australian consciousness. Its biggest effect is bringing to surface smaller truths, particularly through the Bringing Them Home Inquiry. In this essay, I have shown that although smaller truths are important to know alongside the larger truths, it continues to divide Australia and what histories are deemed consensual. As a result, Australia's identity can also be described as divided. 


\section{References}

Attwood, B. 2001, 'Learning about the truth. The stolen generations narrative' in B. Attwood \& F. Magowan (eds), Telling Stories. Indigenous history and memory in Australia and New Zealand, Bridget Williams Books, Wellington, p. $183-212$.

Australian Human Rights Commission 1997, Bringing Them Home. Report of the National Inquiry into the Separation of Aboriginal and Torres Strait Islander Children from Their Families, Canberra, viewed 18 June 2018, < https://www.humanrights.gov.au/publications/bringing-them-home-report$\underline{1997>}$

Bonnell, A. \& Crotty, M. 2008, 'Australia's History Under Howard, 1996-2007', The ANNALS of the American Academy of Political and Social Science, no. 617, p. 149 - 165.

https://doi.org/10.1177/0002716207310818

Darian-Smith, K. \& Hamilton, P. 2013, 'Memory and history in twenty-first century Australia: A survey of the field', Memory Studies, vol. 6, no. 3, p. $370-383$.

https://doi.org/10.1177/1750698013482868

Devitt, R. 2009, "Healing in the heartbreak'?: the role of testimony in the Australian inquiry into the separation of Indigenous children from their families', Humanities Research, vol. 15, no. 3, p. 49 - 70. https://doi.org/10.22459/HR.XV.12.2009.04

Goodall, H. 2002, 'Too early or not soon enough? Reflection on 'sharing' histories as process not collection', Australian Historical Studies, vol. 33, no. 118, p. 7 - 24.

https://doi.org/10.1080/10314610208596176

Manne, R. 2009, 'The history wars', The Monthly, (n.d.) November, viewed 17 June 2018, $<$ https://www.themonthly.com.au/issue/2009/november/1270703045/robert-manne/comment>

McKenna, M. 1997, Different Perspectives on Black Armband History, Research Paper, Parliament of Australia, Canberra, viewed 18 June 2018,

$<$ https://www.aph.gov.au/About_Parliament/Parliamentary_Departments/Parliamentary_Library/pubs/ rp/RP9798/98RP05\#BLACK>

Read, P. 2002, 'Clio or Janus? Historians and the Stolen Generations', Australian Historical Studies, vol. 33, no. 118 , p. 54 - 60. https://doi.org/10.1080/10314610208596179

Thomson, A. 1998, 'Fifty Years On: An International Perspective on Oral History, The Journal of American History, vol. 85, no. 2, p. 581 - 595. https://doi.org/10.2307/2567753

Thomspon, P. \& Bornat, J. 2000, 'History and the Community' in P. Thomspson \& J. Bornat (eds), The Voice of the Past. Oral History, Oxford University Press, New York, p. $1-22$. 